\title{
Sea level pressure variation and major cyclone events in coastal regions of Bangladesh
}

\author{
MA Badhan*, MA Farukh, MA Baten, MAM Hosssen, S Biswas, MS Parvej
}

Department of Environmental Science, Bangladesh Agricultural University, Mymensingh 2202, Bangladesh

\begin{abstract}
The study was conducted in 16 coastal district viz. Satkhira, Khulna, Mongla, Khepupara, Barishal, Bhola, Patuakhali, Hatiya, Chandpur, Feni, Swandip, Sitakunda, Chittagong, Kutubdia, Cox's Bazar and Teknaf of Bangladesh during the period of 1975-2014 to investigate the variation of sea level pressure (SLP) and rainfall. SLP data of 40 years (1975-2014) have been analyzed in this study. The SLP was increasing slightly to the month of September and then a rapid increasing was observed from the month of October to December. Of all the stations, in the month of June and July the lowest SLP was observed in the Khulna region and highest in Teknaf. In the month of December and January the highest and lowest SLP was found in the Month of January. As the fluctuation of SLP was high in the summer season the possibility of cyclone occurrence also rise in this season. The average rainfall is lowest in the station Sitakunda and highest in Swandip. The average rainfall of all district divided the stations into two parts. The rainfall of Barishal, Bhola, Chandpur, Mongla, Sitakunda and Khulna is lower the average of all district. This shows a great instability of weather in these regions. Rest of the stations has the higher average rainfall than the average rainfall of all stations.
\end{abstract}

Key words: Sea level pressure, southern coastal region, cyclone

Progressive Agriculturists. All rights reserve

*Corresponding Author: mehnaz_badhan@yahoo.com

\section{Introduction}

In summer season the sudden decrease of sea level pressure (SLP) is the main reason for cyclone occurrence. As the SLP decrease the weather become unstable and the possibility of causing weather related extreme events increases. Cyclones originate from low atmospheric pressure which is quite common in Bangledesh. They generally occur in early summer from the month April-May or late rainy season from November-December (Choudhury, 1992). Cyclones are responsible for the majority of extreme weather phenomena, governing the time of occurrence as well as the magnitude of their extreme values (Lionello et al., 2006).Farukh and Baten (2015) studied 52 extreme cyclonic events occurred in Bangladesh and also found that lowering the SLP is the trigger of stating an extreme cyclone.

The basic parameters of extra-tropical cyclones in the northern Baltic were examined in relation to extreme sea level events at Estonian coastal stations between 1948 and 2010. The hypothesis was tested that extreme sea level events might be caused not by one intense extra-tropical cyclone, as suggested by earlier researchers, but by the temporal clustering of cyclones in a certain trajectory corridor (Post and Kouts, 2014).

The relationship between Mediterranean precipitation and North Atlantic and European sea level pressure 


\section{Pressure variation and cyclones in Bangladesh}

fields has been studied using statistical techniques to investigate the variability within the data. The largescale pressure fields which facilitate the precipitation patterns have been isolated using a canonical correlation analysis. The pressure-precipitation relationships are found to be very consistent over multi-decadal, seasonal, monthly and daily time-scales with trajectory analysis confirming many of the features of the average seasonal pressure charts (Thompson and Green, 2004).

A storm surge is an extreme short-term (from minutes to a few days) variation in the sea level caused by high winds pushing against the surface of the sea. As the associated flooding threatens lives and property, this phenomenon has been widely described and studied in terms of its physical aspects, with the aim of simulating and forecasting sea-level behavior in case of extreme storm surges (Suursaar et al., 2003; 2006; 2011). On the Polish coast the occurrence of extremely high sea levels depends on three components: a high initial sea level prior to the extreme event; a strong onshore wind that causes tangential wind-stress of the right duration and deformation of the sea surface by mesoscale baric lows and the subsequent production of so-called baric waves, which generate seiche-like variations of the sea level (Wiśniewski and Wolski, 2011).In Bangladesh tropical cyclones are mainly formed due to the presence of low pressure area in $\mathrm{BB}$ and cyclones get momentum from the diurnal motion of the earth (Rahman, 2008). Rainfall is another important parameter for measuring the damages of cyclones. Spring cyclones are characterized with rainfall present lower pressures and higher cyclone propagation velocity in contrast to the ones associated with winter and autumn precipitation events (Iordanidou et al., 2015). Investigating the characteristics of the cyclones causing extreme precipitation is of great interest where the relatively small frequency of adverse weather and extreme events creates a false sense of safety that results many times in more damage and severe socioeconomic consequences (Lionello et al., 2006).
Miglietta et al. (2013) found that it is before the mature cyclone phase when the most intense convective activity and rainfall happens. So, that not only the heavy wind but the heavy rainfall also causes great damage to the areas where cyclones occur. Cyclones bring enormous rainfall along with it. This huge amount of rainfall causes rising the sea level which result in storm surges. Tsanis et al. (2012) and Jansa et al. (2001b) performed an analysis of cyclones associated with flood events, concentrating on the genesis, tracks and depth of those systems and found flood events are highly related to specific cyclone pathways. Cyclones trigger heavy rainfall result in flood events which is a great concern for the country like Bangladesh. Therefore, the present work was undertaken to find out the SLP and rainfall variation in southern coastal region of Bangladesh and relation of SLP and rainfall with cyclogenesis.

\section{Methodology}

\section{Study Area}

This study was conducted in the southern coastal region of Bangladesh. Bangladesh is located between $20^{\circ}$ to $26^{\circ}$ North and $88^{\circ}$ to $92^{\circ}$ East. It is bordered on the west, north and east by India, on the south-east by Myanmar, and on the south by the BB. Most of the country is low-lying land comprising mainly the delta of the Ganges and Brahmaputra rivers. Floodplains occupy $80 \%$ of the country. Mean elevations range from less than 1 meter on tidal floodplains, 1 to 3 meters on the main river and estuarine floodplains, and up to 6 meters in the Sylhet basin in the north-east (Rashid, 1991). Only in the extreme northwest are elevations greater than 30 meters above the mean sea level. The northeast and southeast portions of the country are hilly, with some tertiary hills over 1000 meters above mean sea level (Huq and Asaduzzaman, 1999). We conducted our study in Satkhira, Khulna, Mongla, Khepupara, Barishal, Bhola, Patuakhali, Hatiya, Chandpur, Feni, Swandip, Sitakunda, Chittagong, Kutubdia, Cox's Bazar and Teknaf. 
Bangladeshi coastal areas faced fifty two major cyclones in the $19^{\text {th }}$ century. During last 10 years of the present century, coastal areas have faced at least four devastating cyclones. The number of death and loss of socio-economic condition are also increasing with the increasing number of cyclones.

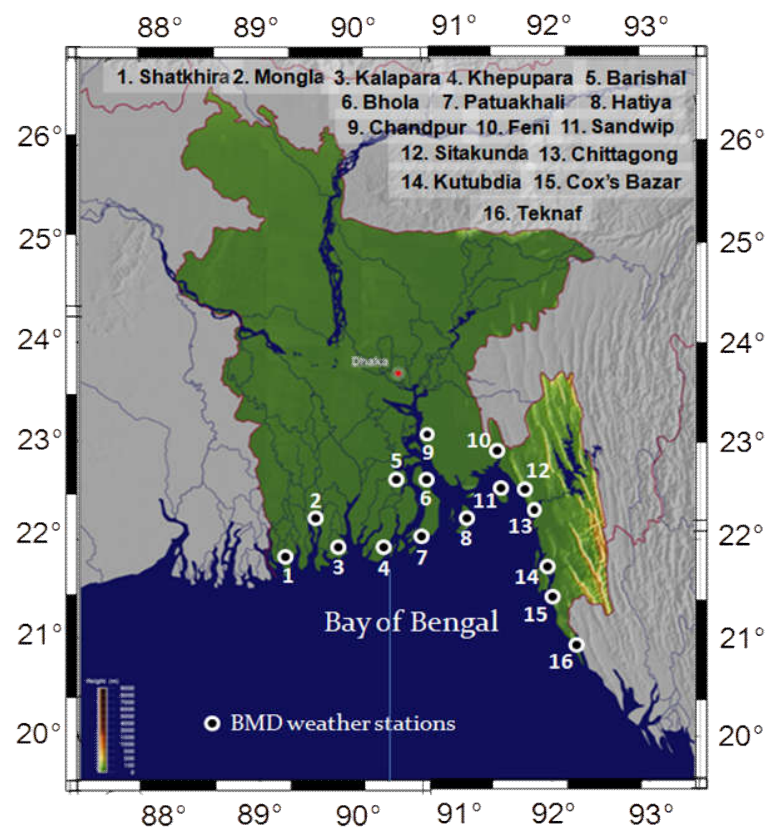

Figure 1. GIS plotting of 16 stations in southern coastal region of Bangladesh

From Table 1 it is found that the number of cyclone occurrence is increasing with the increasing number of cyclones occurrence in the coastal areas of Bangladesh.

\section{Weather Data}

The in-situ data of climatic variables was collected from Bangladesh Meteorological department (BMD) at 16 measuring points from 1975 to 2014.

\section{Data Analyses}

\section{Data Processing}

All the collected data were then compiled, tabulated, and analyzed according to the objectives of the study. Weather data, sea level pressure (SLP) in hPa were calculated using frequently used statistical software MS Excel-2010 to analyze the variation and trend line.
MS Office Picture Manager and Paint were applied to analyze data as per objectives of the study.

Table 1. Chronology of major cyclones in Bangladesh (compiled from Khalil MG (1992), Murty TS, El-Sabh MI (1992), Ahmed et al., 2012)

\begin{tabular}{|c|c|c|}
\hline $\begin{array}{c}\text { Year of } \\
\text { Occurrence }\end{array}$ & $\begin{array}{c}\text { Velocity } \\
\text { (Km/h) }\end{array}$ & $\begin{array}{c}\text { Number of } \\
\text { Death }\end{array}$ \\
\hline 1822 & - & 40000 \\
\hline 1872 & - & 270 \\
\hline 1876 & - & 400000 \\
\hline 1897 & - & 175000 \\
\hline 1911 & - & 120000 \\
\hline 1917 & - & 70000 \\
\hline 1919 & - & 40000 \\
\hline 1926 & - & 606 \\
\hline 1941 & - & 7000 \\
\hline 1958 & - & 12000 \\
\hline 1960 & - & 11446 \\
\hline 1960 & 210 & 8149 \\
\hline 1961 & 145 & 11468 \\
\hline 1961 & 145 & 10466 \\
\hline 1962 & 200 & 50000 \\
\hline 1963 & 201 & 11520 \\
\hline 1965 & 161 & 19970 \\
\hline 1965 & - & 12000 \\
\hline 1965 & 200 & 870 \\
\hline 1966 & - & 850 \\
\hline 1967 & 130 & 128 \\
\hline 1969 & - & 175 \\
\hline 1970 & 222 & 500000 \\
\hline 1971 & 110 & 11000 \\
\hline 1973 & 122 & 183 \\
\hline 1983 & 122 & 1043 \\
\hline 1983 & 136 & 300 \\
\hline 1985 & 154 & 11069 \\
\hline 1988 & 160 & 5708 \\
\hline 1990 & - & 150 \\
\hline 1991 & 235 & 145000 \\
\hline 1997 & 225 & 126 \\
\hline 2007 & 200 & 3406 \\
\hline 2008 & 215 & 138,366 \\
\hline 2009 & 120 & 339 \\
\hline 2013 & 95 & 0 \\
\hline 2015 & 90 & 20 \\
\hline & & \\
\hline & - & - \\
\hline
\end{tabular}




\section{Results and Discussion}

\section{Sea level pressure and rainfall variation in southern coastal region of Bangladesh}

We have studied 16 coastal stations and try to find out the most affected region by cyclone. In this part we have presented the 7 most affected coastal areas among the 16 areas we have studied.

\section{Chittagong (Patenga)}

Patenga is a sea port area situated in the Chittagong region. The figure 2(a) is drawn by using monthly SLP data in $\mathrm{hPa}$ of the year 1975-2014. SLP of this area was highest in the month of January and gradually decreased in the month of June. The average lowest and highest SLP observed in this region is $999 \mathrm{hPa}$ and $1017 \mathrm{hPa}$ respectively. The highest SLP was $1015 \mathrm{hPa}$ in the month of January and lowest $1002 \mathrm{hPa}$ in the month of June. Rather than decreasing, the SLP of this area slightly increased in the month of July. The surrounding water bodies have a great influence on its weather pattern. Figure 2(b) is showing the rainfall of Patenga from the year 1975-2014 in mm. By this figure we can easily understand the long term rainfall of Patenga. The minimum average rainfall is observed in the month of December and the value is $6 \mathrm{~mm}$. The maximum average rainfall is observed in the month of July and the value is $711 \mathrm{~mm}$. The maximum rainfall in this region is observed $1457 \mathrm{~mm}$ in the month of August. From the 1500 century around 21 cyclonic storms caused great damage to this coastal area and caused huge death of animal and human. Infrastructural damages caused billions of dollar loss (Ahmed et al., 2012). Cyclones of 1797, 1876, 1897, 1948, 1958, 1960, 1963, 1966, 1970, 1971, 1974, 1977, 1983, 1985, 1986, 1991, 1997, 1998, 2007, 2009 and 2015 blown over this coastal region. From 1975-2014, ten cyclones hit this region resulting great damage. The more recent occurring cyclone Komen hit near Chittagong. About 510,000 houses in the country were damaged or destroyed, and many residents lost their source of income as 667,221 acres $(270,000 \mathrm{ha})$ of crop fields were damaged. The floods killed 132 people, of which at least 39 were directly related to Komen. In 2016, Cyclone Roanu made landfall near Chittagong killing 26 people in Bangladesh. Around 40,000 homesteads and business houses were damaged. Food storage, seasonal crops were damaged. Livestock, including fish and shrimp firms were swept away.

\section{Cox's Bazar}

The longest sea beach of the world is situated in this region. The figure 2(c) is drawn by using monthly SLP data of the year 1975-2014.The average lowest and highest SLP observed in this region was $999 \mathrm{hPa}-$ 1016hPa. The minimum SLP of the region was $996 \mathrm{hPa}$ in the month of July and maximum SLP was 1019hPain the month of January. The SLP was highest in the month of December and gradually decreased in the month of July. Figure 2(d) is showing the rainfall of Cox's Bazar from the year 1975-2014 in mm. The minimum average rainfall is observed in the month of January and the value is $4 \mathrm{~mm}$. The maximum average rainfall is observed in the month of July and the value is $823 \mathrm{~mm}$. Whereas, the maximum rainfall in this region is observed $1730 \mathrm{~mm}$ in the month of July. Cyclones of 1963, 1965, 1974, 1975, 1983, 1985, 1994, 1995, 1997, 1998, severe cyclone Sidr, Aila and Komen caused damages in this area over the year. Recently, Cyclone Komen hit near Chittagong and Cox's Bazar. About 510,000 houses in the country were damaged or destroyed, and many residents lost their source of income as 667,221 acres $(270,000 \mathrm{ha})$ of crop fields were damaged. The floods killed 132 people, of which at least 39 were directly related to Komen.

\section{Barishal}

The SLP in figure 2(e) of this area was highest in the month of January and gradually decreased in the month of July. The minimum SLP of the region is $993 \mathrm{hPa}$ and highest $1020 \mathrm{hPa}$ in the month of June and January respectively. Figure 2(f) is showing the rainfall of Barishal from the year 1975-2014 in mm. By this figure we can easily understand the long term rainfall of Barishal. The minimum average rainfall was 
observed in the month of December $(7 \mathrm{~mm})$. The maximum average rainfall is observed in the month of July $(400 \mathrm{~mm})$, whereas, the maximum rainfall was $1076 \mathrm{~mm}$ in September. Cyclones of 1554, 1822, 1831, 1876, 1958, 1965, 1977, 1983, 1985, 1986, 1988, 1991, 1998, cyclone Sidr, Aila attacked this region. From the year 1975-2014, nine cyclones attacked this area severely. In 1983 cyclone, $1.52 \mathrm{~m}$ storm surge attacked the study area and 300 fishermen with 50 boats got missing. In 1988 a severe cyclonic storm (Cyclone04B) struck Jessore, Kushtia, Faridpur and coastal islands of Barisal and Khulna 5,708 people died and numerous wild animals at the Sundarbans (deer 15000, Royal Bengal Tiger 9) washed away. 65,000 cattle died because of the cyclonic storm surge. Total damage to crops reached Taka 9.41 billion. A cyclone hit the coastal islands and chars near Patuakhali, Barisal, Noakhali and Chittagong in1991 and the storm surge was $1.9 \mathrm{~m}$. In 1998 cyclone, coastal islands and sand shoals near Khulna, Barisal, and Patuakhali were hit by 1.22 to $2.44 \mathrm{~m}$ storm surge.

\section{Patuakhali}

The district is situated at southernmost part of the country. The SLP of this area (figure $2(\mathrm{~g})$ ) is highest in the month of December and gradually decreased and the lowest in the month of July. The lowest average of SLP observed in this region was $998 \mathrm{hPa}$ in the month of July and highest average was $1017 \mathrm{hPa}$ in the month of December. The minimum SLP was 993hpa observed in the month of July and maximum SLP was $1020 \mathrm{hPa}$ in the month of January. Figure 2(h) is showing the rainfall of Patuakhali from the year 1975-2014 in mm. By this figure we can easily understand the long term rainfall of Patuakhali. The minimum average rainfall is observed in the month of December and the value is $5 \mathrm{~mm}$. The maximum average rainfall is observed in the month of June and the value is $520 \mathrm{~mm}$ which is greater than the nearby station Bhola. The maximum rainfall in this region is observed $1084 \mathrm{~mm}$ in the month of June. Cyclones in 1584, 1960, 1965, 1970, 1973, 1977, 1983, 1986, 1991, 1998 and severe cyclone Aila occur in
2015 cause this coastal region with a great damage. From 1975-2014 six cyclones attacked this region. Among these the most deadly was the cyclone in 1983 which cause death of 300 fishermen and 50 boats got missing. The storm surge was $1.52 \mathrm{~m}$. Two thousands of houses were damaged. In 1986 a severe cyclonic storm hit the coastal island and chars near Chittagong, Barisal, Patuakhali and Noakhali. Maximum wind speed was $110 \mathrm{kmh}^{-1}$ at Chittagong and $90 \mathrm{kmh}^{-1}$ at Khulna. Fourteen people lost their life. About $972 \mathrm{~km}^{2}$ of paddy fields were inundated; Schools, mosques, warehouses, hospitals, houses and buildings were destroyed at Amtali upazila in Barguna District. In 1998 a storm surge of $1.22 \mathrm{~m}$ to $2.44 \mathrm{~m}$ hit coastal islands and sand shoals near Khulna, Barisal, and Patuakhali.

\section{Khulna}

This district is situated at southern part of the country. The figure 2(i) is drawn by using monthly SLP data of the year 1975-2014 which shows us the maximum, minimum, average, average + sd and average-sd of SLP in this region. The SLP of this area (Figure 2(j)) was highest in the month of January and gradually decreases in the month of July. The average lowest SLP observed in this region was $997 \mathrm{hPa}$ in the month of January and $1017 \mathrm{hPa}$ is highest in the month of July. The minimum SLP of the region was $993 \mathrm{hPa}$ observed in the month of July and maximum SLP was $1021 \mathrm{hPa}$ observed in the month of January. As the SLP decreased the possibility increased for the cyclone occurrence. Figure 4 is drawn by using the long term rainfall in $\mathrm{mm}$ from the year 1975- 2014. From this figure we can easily observe that in Khulna the rainfall increases from the month of April and decreases from the month of November. July and August receive comparatively low rainfall that increases in the month of September. The average lowest rainfall observed in the month of December and highest average rainfall observed in the month of June and the value is $7 \mathrm{~mm}$ and $332 \mathrm{~mm}$ respectively. The maximum rainfall $846 \mathrm{~mm}$ of the year observed in the month of June. As 


\section{Pressure variation and cyclones in Bangladesh}

we already know association of rainfall with cyclone is very common phenomena. Because of its location this region got affected by cyclone very frequently. A huge number of cyclone attack the Khulna and its coast line in many years. In 1909, 1917, 1961, 1966, 1970, 1971, 1974, 1975, 1977, 1978, 1986, 1988, 1998 causes great damage both to infrastructure and livelihood. From 1975-2014, 6 cyclones attacked the coast line of Khulna. Among all these cyclones the most dead liest was in 1988. A severe cyclonic storm (Cyclone-04B) struck Jessore, Kushtia, Faridpur and coastal islands of Barisal and Khulna. 5,708 people died and numerous wild animals at the Sundarbans (deer 15000, Royal Bengal Tiger 9) washed away. 65,000 cattle died because of the cyclonic storm surge. Total damage to crops reached Taka 9.41 billion. In 1998 a storm surge of 1.22 to 2.44 metres hit coastal islands and sand shoals near Khulna, Barisal, and Patuakhali.

\section{Bhola}

Bhola is another important area in the southern part of Bangladesh. It is covered by the rivers and that's why it is known as the largest island in Bangladesh. In this area the highest SLP was in the month of January and gradually decreased in the month of July (figure 2(k)). The average lowest SLP is $998 \mathrm{hPa}$ and highest average is $1017 \mathrm{hPa}$ in the month of June and December, respectively. The minimum SLP of the region was 993hpa in the month of June and maximum SLP was $1023 \mathrm{hPa}$ in the month of January. As the SLP decrease the weather become unstable and the possibility of causing weather related extreme events increase. It is very clear that the weather started to become unstable as the summer season start. The cyclones in 1975, 1991, 1997 and Aila attacked this area in the month of April or May which support the theory. In the other hand, in 1970 and another cyclone in 1997 hit the area in the end of summer season (September-November). Figure 2(l) is showing the rainfall of Bhola from the year 1975-2014 in mm. By this figure we can easily understand the long term rainfall of Bhola. The minimum average rainfall is observed in December (5mm). The maximum average rainfall is observed in June $(440 \mathrm{~mm})$. The maximum rainfall in this region is observed $993 \mathrm{~mm}$ in the month of September. Cyclones bring huge rainfall which cause storm surge. In this region the cyclone causing storm surge was $1.83 \mathrm{~m}$ to $3.05 \mathrm{~m}$ in 1997 . One hundred and twenty six people died in the affected areas. In 1997, 25-27 September a severe cyclonic storm hit coastal islands near Chittagong, Cox's Bazar, Noakhali and Bhola. It had wind speeds up to $150 \mathrm{kmh}^{-1}$, and a storm surge of $1.83 \mathrm{~m}$ to $3.05 \mathrm{~m}$.

\section{Hatiya}

Hatiya is an Island which is situated in the southern part of the country. The SLP of this area (Figure $2(\mathrm{~m})$ ) was highest in the month of December and gradually decreases in the month of June. The average lowest SLP is $998 \mathrm{hPa}$ and $1016 \mathrm{hPa}$ in the month of June and December respectively. The minimum SLP of the region was $993 \mathrm{hPa}$ and maximum SLP is $1019 \mathrm{hpa}$ also in the months of June and December.

As the SLP decrease the weather become unstable and the possibility of causing weather related extreme events increases. As the summer season has the lowest SLP most of the cyclones occur in this time. Cyclones of 1822, 1963, 1983 and cyclone Sidr occur in May dramatically. Farukh and Baten (2015) also stated that this season is the second most cyclone occurring season. Figure 2(n) is showing the rainfall of Hatiya from the year 1975-2014 in $\mathrm{mm}$. The minimum average rainfall is observed in the month of December and the value is $11 \mathrm{~mm}$. The maximum average rainfall is observed in the month of July and the value is $734 \mathrm{~mm}$. The maximum rainfall in this region is observed $1311 \mathrm{~mm}$ in the month of August. From the year 1975-2014, three deadliest cyclones attacked this area causing great damages. In the year 1985, a severe cyclone hit Chittagong, Cox's Bazar, Noakhali and coastal islands (Sandwip, Hatiya, and Urirchar). Maximum wind speed at Chittagong was $154 \mathrm{kmh}^{-1}$, at Sandwip was $140 \mathrm{kmh}^{-1}$, and at Cox's Bazar was $100 \mathrm{kmh}^{-1}$. The storm surge reached a height of $3.0 \mathrm{~m}$ - 
$4.6 \mathrm{~m}$. damages were severe along with death of 11,069 people and 135,033 cattle. Seventy four kilometers of road and embankments destroyed with 94,379 houses.

\section{Ensemble means of sea level pressure}

The Figure 3 represents the Ensemble Means of SLP in $\mathrm{hPa}$ of all the 16 stations studied here. The figure is drawn by using the average SLP of Satkhira, Khulna, Mongla, Khepupara, Barishal, Bhola, Patuakhali, Hatiya, Chandpur, Feni, Swandip, Sitakunda, Chittagong, Kutubdia, Cox's Bazar and Teknaf, and the average of SLP of all 16 stations. From this figure, we can easily observe that the SLP was decreasing from the month of January and lowest in the month of June. Then the SLP was increasing slightly to the month of September and then a rapid increasing was observed from the month of October to December. Of all the stations in the month of June and July the lowest SLP was observed in the Khulna region and highest in Teknaf. In the month of December and January the highest and lowest SLP was found in the Month of January.

As we stated before, in September and October the SLP showed a rapid change which has a great possibility of occurring weather related extreme events. In fact many researchers also showed that in these months $60 \%$ of all cyclones occur (Farukh and Baten, 2015; Chowdhury, 2007). March to June is second most vulnerable time for the formation of cyclone, because on an around 45\% of cyclone from 1952-2010 has occurred in this time (Ali, 1999).

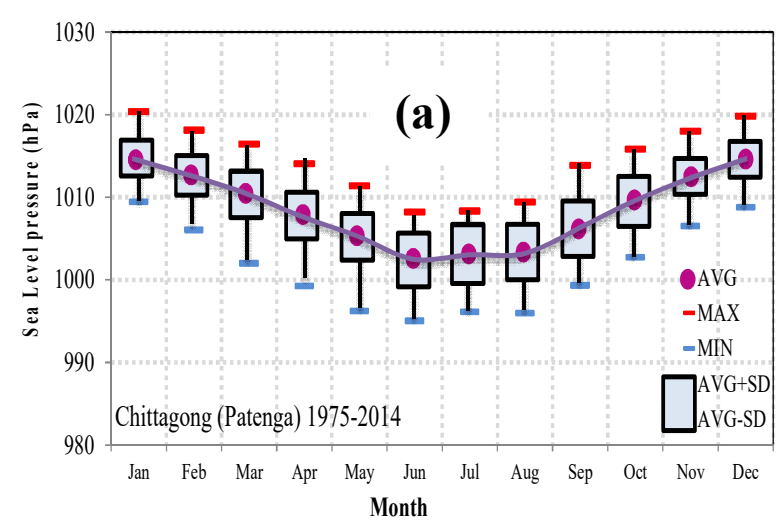

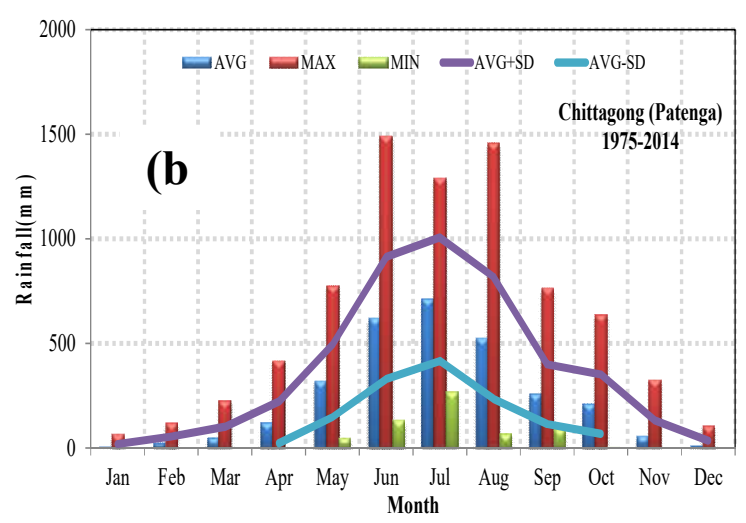
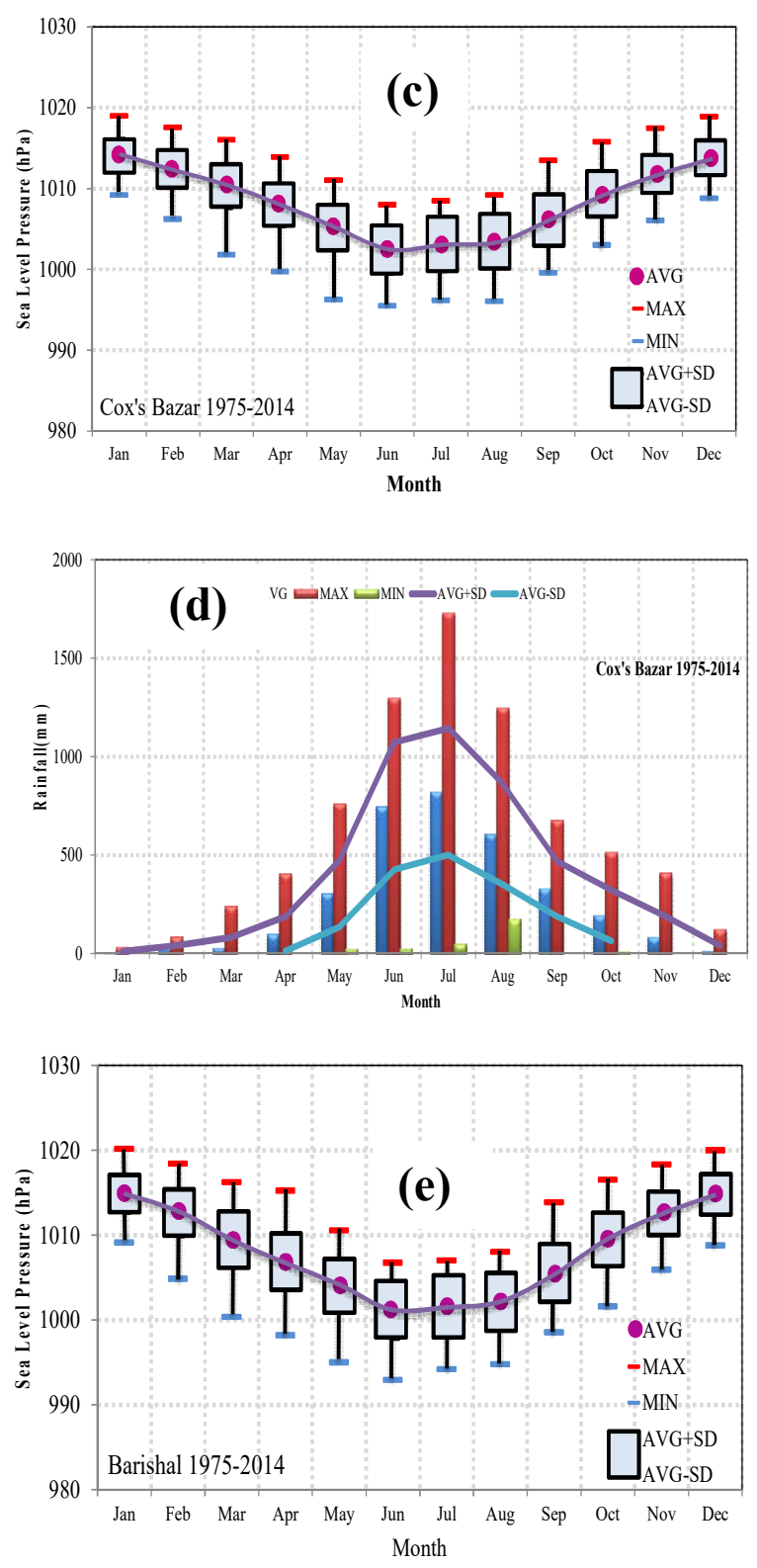

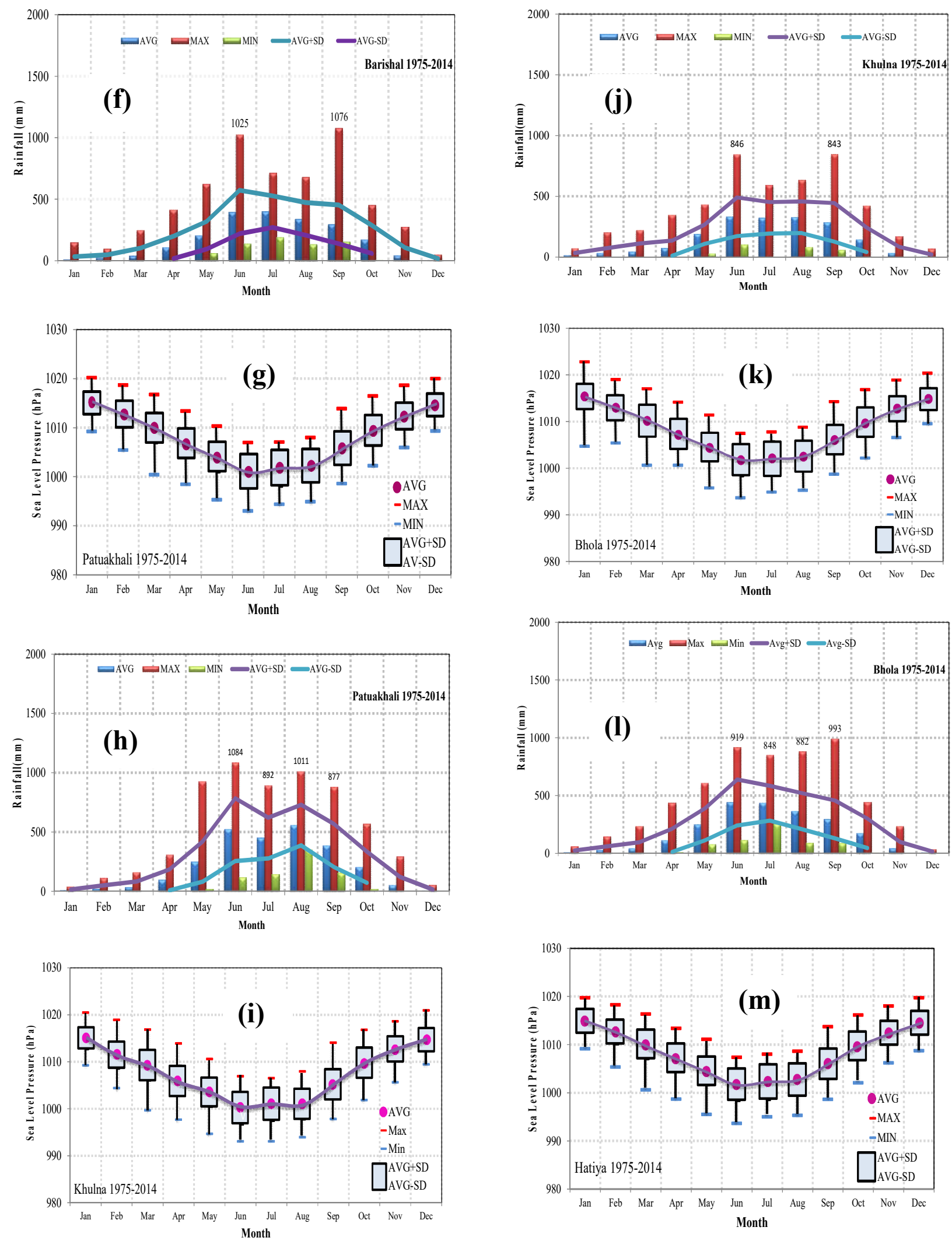


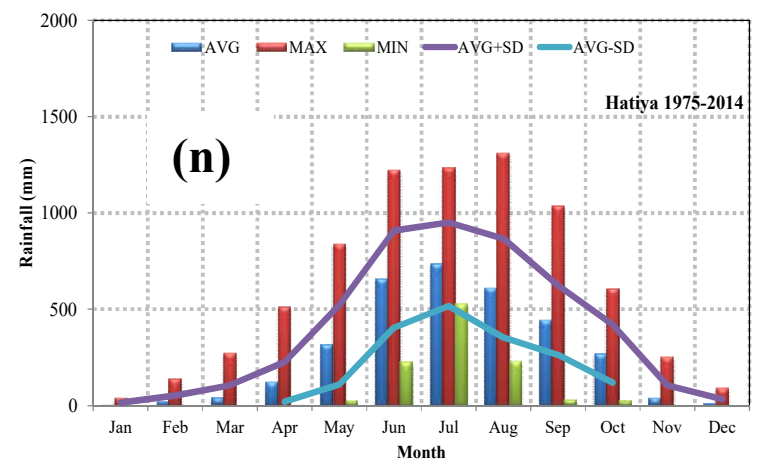

Figure 2. Monthly SLP (hPa) and rainfall of (a), (b) Chittagong (c), (d) Cox's Bazar (e), (f) Barishal (g), (h) Patuakhali (i), (j) Khulna (k), (l) Bhola (m), (n) Hatiya from 19752014.

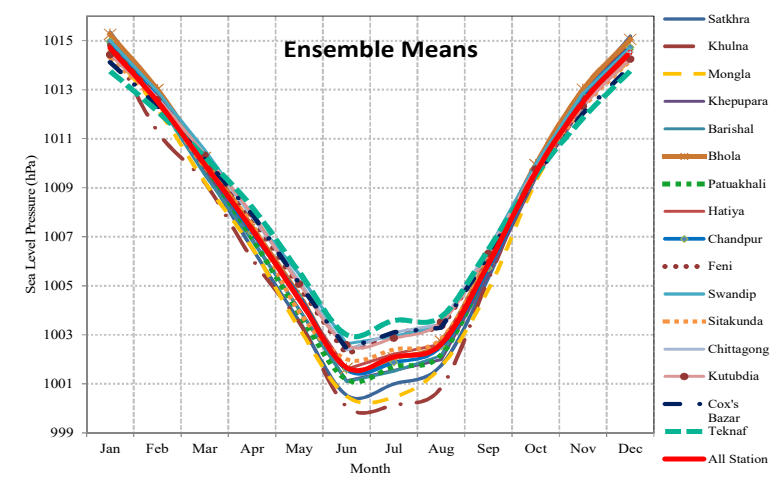

Figure 3. Ensemble means of SLP (hPa) of 16 stations from 1975-2014.

Severe cyclone Aila, Komen and Royanu also occur in this time period. Rahman (2008) stated that the one of the main cause of cyclone formation in BB is presence of low pressure area. As the fluctuation of SLP was high in the summer season the possibility of cyclone occurrence also rise in this season.

\section{Ensemble Means of Rainfall}

Figure 4 shows the ensemble means of rainfall of all 16 stations we studied. The figure is drawn by using the average rainfall of Satkhira, Khulna, Mongla, Khepupara, Barishal, Bhola, Patuakhali, Hatiya, Chandpur, Feni, Swandip, Sitakunda, Chittagong,
Kutubdia, Cox's Bazar and Teknaf and the average rainfall of all 16 stations. By this figure we can easily see that the average rainfall is lowest in the station Sitakunda and highest in Swandip. As we know the higher the rainfall lower the temperature and lower the rainfall indicate higher the temperature. The average rainfall of all district divided the stations into two parts. The rainfall of Barishal, Bhola, Chandpur, Mongla, Sitakunda and Khulna is lower the average of all district. This shows a great instability of weather in these regions. Rest of the stations has the higher average rainfall than the average rainfall of all stations.

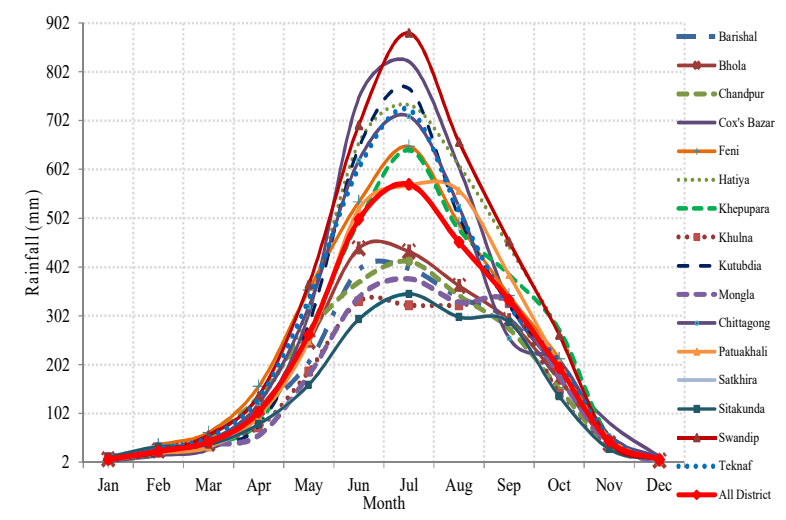

Figure 4. Ensemble means of rainfall $(\mathrm{mm})$ of 16 stations from 1975-2014

This is an important indicator of higher unstable weather situation in these areas. Because lower rainfall result is higher the temperature which can cause many cyclonic events in these areas. Hawcroft et al. (2012) evaluated the contribution of midlatitude cyclones to the precipitation of the Northern Hemisphere, showing association of precipitation with cyclones by over $70 \%$ in two different reanalysis dataset. Cyclone Komen struck in 2015 with a storm surge of 1.22 to 2.44 meters hit near Chittagong. About 510,000 houses in the country were damaged or destroyed, and many residents lost their source of income as 667,221 acres (270,000 ha) of crop fields were damaged. 


\section{Pressure variation and cyclones in Bangladesh}

\section{Conclusion}

The study was conducted to investigate the variation of SLP in southern coastal region of Bangladesh from 1975 to 2014. We investigate the association of SLP with extreme cyclone events. The SLP was increasing slightly to the month of September and then a rapid increasing was observed from the month of October to December. Of all the stations in the month of June and July the lowest SLP was observed in the Khulna region and highest in Teknaf. In the month of December and January the highest and lowest SLP was found in the Month of January. As the fluctuation of SLP was high in the summer season the possibility of cyclone occurrence also rise in this season.SLP is the most important factor that has a role behind the cyclone occurrence. The trend of SLP in the 16 stations we studied shows a homogenous curve where from December to July SLP decreases and then it stared to increase. Sudden fluctuation of SLP was found in most of the station in the month of April-May when most of the cyclones occur.

Rainfall association with cyclone is very common phenomena that cause storm surges. In May-June, rainfall is highest in all of 16 stations. So a sudden storm surge caused by rainfall can resulted in a prolonged flood or flush flood. The average rainfall of all district divided the stations into two parts. The rainfall of Barishal, Bhola, Chandpur, Mongla, Sitakunda and Khulna is lower the average of all district. This shows a great instability of weather in these regions. Rest of the stations has the higher average rainfall than the average rainfall of all stations.

\section{Acknowledgements}

The authors thank to Bangladesh Meteorological Department (BMD), Agargaon, Dhaka, Bangladesh for providing an immense number of weather datasets. This study was partially supported by the University Grants Commission (UGC), Bangladesh through the research Project No. 2015/248/UGC.

\section{References}

Ahmed S, Rahman MM, Faisal MA (2012). Reducing Cyclone Impacts in the Coastal Areas of Bangladesh: A Case Study of Kalapara Upazila. $J$. Bd. Inst. Planrs. 5: 185- 197.

Choudhury AM (1992). Cyclones and the coastal zones of Bangladesh, T. Bd. Quartl. Dept. of Films and Publications.

Farukh MA, Baten MA (2015). Temperature Anomaly and Severe Cyclone Eventin the Southern Coastal Regions of Bangladesh.J. Environ. Sci. \& Nat. Res. 8(1): 35-40.

Huq S, Asaduzzaman M (1999). Overview: In Vulnerability and Adaptation to Climate Change for Bangladesh,S. Huq, Z. Karim, M. Asaduzzaman, and F. Mahtab (eds.). Kluwer AcademicPublishers, Dordrecht, The Netherlands. pp. 1-11.

Iordanidou A; Koutroulis G, Tsanis IK (2015). Mediterranean cyclone characteristics related to precipitation occurrence in Crete, Greece. Nat. Haz. E. Sys. Sci. 15: 1807-1819. www.nathazards-earth-syst-sci.net/15/1807/ 2015/. doi:10.5194/nhess-15-1807-2015.

Jansa A, Genoves A, Picornell MA, Campins J, Riosalido R, Carretero O (2001). Western Mediterranean cyclones and heavy rain. Part 2: Statistical approach. Meteorol. Appl. 8: 43-56. doi:10.1017/S1350482701001049.

Khalil GM (1992). Cyclones and Storm Surges in Bangladesh: Some Mitigative measures, Nat. Haz. 6: 11-24.

Lionello P. Bhend J. Buzzi A. Della-Marta PM, Krichak SO, Jansa A, Maheras P, Sanna A, Trigo IF, Trigo R (2006). Cyclones in the Mediterranean Region: Climatology and Effects on the Environment, in: Mediterranean Climate Variability, Amsterdam. pp. 325-372.

Miglietta MM, Laviola S, Malvaldi A, Conte D, Levizzani V, Price C (2013). Analysis of tropicallike cyclones over the Mediterranean Sea through a combined modeling and satellite approach, 
Geophys. Res. Lett. 40: 2400-2405. doi:10.1002/grl.50432.

Murty TS, El-Sabh M (1992). Mitigating the effects of storm surges generated by tropical cyclones-A proposal. Nat. Hazards. 6(3): 251-273.

Post P, Kouts T (2014). Characteristics of cyclones causing extreme sea levels in the northern Baltic Sea. Oceanologia. 56 (2): 241-258.

Rahman MA (2008). Preparedness for Cyclonic Disaster in coastal areas of Bangladesh and Impact assessment of cyclone SIDR. An Unpublished BURP thesis, Department of Urban and Regional Planning, Jahangirnagar University, Savar, Dhaka.

Rashid HE (1991). Geography of Bangladesh (Second Revised Edition), The University Press Ltd., Dhaka, Bangladesh.

Suursaar U, Jaagus J, Kullas T, Tonisson H (2011). Estimation of sea level rise and storm surge risks along the coast of Estonia, Baltic Sea - a tool for coastal management. http://dx.doi.org/10.1051/litt/201112005.

Suursaar U, Kullas T, Otsmann M, Saaremae I, Kuik J, Merilain M (2006). Cyclone Gudrun in January
2005 and modelling its hydrodynamic consequences in the Estonian coastal waters. Boreal Environ. Res. 11 (2): 143 -159.

Suursaar U, Kullas T, Otsmann M, Kouts T (2003). Extreme sea level events in the coastal waters of western Estonia. J. Sea Res., 49 (4): 295-303. http: //dx.doi.org/10.1016/S1385-1101(03)00022-4.

Thompson R, Green DN (2004). Mediterranean precipitation and its relationship with sea level pressure patterns. Anls. Geophyc., 47 (5): 16171633.

Tsanis IK, Koutroulis AG, Flocas HA, Kaminari M, Kouroutzoglou J, Simmonds I (2012). Atmospheric circulation patterns associated with flood events in Crete, Greece, in Protection and restoration of the environment, Thessaliniki, Greece. pp. 1842-1852.

Wiśniewski B, Wolski T (2011). Physical aspects of extreme storm surges and falls on the Polish coast. Oceanol. 53 (1-TI): 373-390,.http://dx.doi.org/10. 5697/oc.53-1-TI.373. 